\title{
The European Union, the Arctic, and International Law
}

\author{
Joaquín Alcaide-Fernández \\ University of Seville, Seville, Spain
}

\begin{abstract}
The European Union (EU) is willing to participate as much as possible at the negotiation table to meet the challenges that the Arctic poses and benefit from the opportunities it offers. But the relationship between the EU and the Arctic is 'problematic' for both external (EU difficulties particularly with Canada and Russia) and internal reasons (substantive competing interests and ambivalent policies, discrepancies among member States and within E U institutions ...). Without a specific policy tradition or a direct geographical link, the EU has not yet gained legitimacy to become a key 'Arctic actor' or stakeholder. The EU needs to take an active stance on issues relating to the Arctic (including maritime delimitation, which is critical for determining navigational rights, the scope of Art. 234, etc.); because otherwise, the EU reduces its chances to make an impact on the relevant international fora and, ultimately, on making and implementing Arctic international law.
\end{abstract}

\section{Keywords}

European Union (EU) - Arctic challenges and opportunities - Arctic actors - Arctic E U law - EU and Arctic international law

\section{Introduction: Arctic Global Governance?}

There has been, and there still will be, much discussion on the role of nonArctic States and other non-Arctic international actors in Arctic governance, i.e., international cooperation on Arctic issues. Since the renewed 'visibility' of Arctic matters in 2007 - when it was broadcasted that Russia had started 
the so-called 'race for the Arctic' ... -, ', it seems that several old and 'new'2 Arctic issues have gained a global dimension, thus going beyond the exclusive interests of Arctic States: scientific research, security issues, indigenous peoples' rights, sustainable development-including exploration, exploitation and conservation of fisheries-, mineral resources, navigation, tourism, environmental protection - particularly the fight against climate change and its consequences-, among many other topics. ${ }^{3}$ Somehow, the undoubted relevance acquired by the Arctic today (from political, social, economic, geostrategic and scientific perspectives) entails an intermingling of challenges, risks and opportunities. Climate change poses a huge environmental challenge (ice loss, sea level rise, etc.), but it also opens vast economic opportunities in the Arctic, such as easier access to resources, transpolar shipping through Russia's Northern Sea Route (NSR) or the American Northwest Passage (NWP). At the same time, these opportunities present new environmental risks and challenges - mainly related to overexploitation and pollution - in a very sensitive region.

International cooperation on Arctic issues involves different interests and stakeholders, based not only on geographical reasons (consider the concentric circles around the North Pole that expand over the Arctic Ocean, the Arctic Polar Circle and beyond), but also due to socio-economic and political factors.

Regarding Arctic issues, we need to take into account three different groups of States and actors. First, the coastal Arctic States, that is: Canada, the Kingdom of Denmark (Greenland), Norway, the Russian Federation and the United States of America. Second, we find other Arctic States whose sovereign territory includes areas above the Arctic Polar Circle (Finland, Iceland and Sweden). Arctic States hold formal and informal meetings on a regular basis

1 On 2 August 2007, in the Arktika 2007 expedition, two Russian mini-submarines planted a titanium Russian flag on the seabed under the North Pole, giving rise to a media narrative filled with inflamed political rhetoric and sensationalist metaphors, such as comparing that fact with the arrival of man on the moon. As is now well known, there is not really a 'race' for the Arctic, but a coordinated effort of Arctic States, particularly coastal Arctic States, to govern the region.

2 The reports about the Arctic ice loss have coincided with others about the Arctic holding a non-negligible percentage of the world's remaining undiscovered conventional oil and gas resources.

3 On the coexistence of Arctic States and international cooperation on Arctic issues, see C Cinelli, El Ártico ante el derecho del mar contemporáneo (Tirant lo Blanch-Universidad de Sevilla, Valencia, 2012). On the legal challenge that climate change entails in the Arctic, see M Sobrido-Prieto (ed), Espacios polares y cambio climático. Desafíos jurídico-internacionales (Tirant lo Blanch, Valencia, 2017). 
at the Arctic Council (AC), which was founded in 1996 as a high-level intergovernmental forum for purposes of cooperation and coordination on matters of common concern. Decisions are made by consensus and Arctic indigenous peoples' organizations hold the unique position of 'permanent participants', which gives them full consultation rights in Council decision-making. ${ }^{4}$ Third, there are other interested States and other actors, that is, non-Arctic States and non-wholly-Arctic international actors that have presented their 'credentials' as Arctic stakeholders and have been accepted by Arctic States as such. ${ }^{5}$

The United Nations Convention on the Law of the Sea (LOSC) ${ }^{6}$ is applicable to the Arctic. Though the Us is yet to accede to it, the Convention has been affirmed as the 'general regulation'7 on Arctic ocean governance by the coastal Arctic States themselves. ${ }^{8}$ All coastal Arctic States possess a 200-nautical-mile $(\mathrm{nm})$ exclusive economic zone (EEZ) and their continental shelves extend to a distance of $200 \mathrm{~nm}$ from the baselines from which the breadth of the territorial sea is measured; however, the EEz has not been established around the Svalbard archipelago. In this regard, Norway (2006), Russia (2007), Canada (2013), and Denmark (2014) have launched projects to provide a basis for seabed claims on extended continental shelves beyond the 200-nm limit in some areas. ${ }^{9}$ Beyond the marine disputes over limits of the outer continental shelves,

4 In 2014 the Arctic Economic Council (AEC) was launched during Canada's AC chairmanship (2013-2015, Leona Aglukkaq being the first Inuk ever to chair the AC) to address the very real economic challenges of Northerners with a strong focus on the northern voice.

5 As we will see, numerous States and the European Union (EU) have expressed a keen interest in joining the cooperation in Arctic issues through the AC, but in 2009 the Council (i.e., the Arctic States) re-evaluated the observer role and adopted new acceptance criteria. Also, in 2013 a new network of international dialogue and cooperation on the future of the Arctic - the so-called Arctic Circle-was launched in order to strengthen the policy-making process by bringing together as many Arctic and international players as possible. Held in Reykjavik (Iceland), the 2016 Assembly was well attended by more than 2.000 participants from 50 States and could be depicted as an open invitation to interested parties worldwide to exchange ideas on a wide range of issues.

6 United Nations Convention on the Law of the Sea (Montego Bay, 10 December 1982, in force 16 November 1994) 1833 UNTS 396.

7 Without prejudice to other 'specific rules', such as the International Maritime Organization's (IMO) International Code for Ships Operating in Polar Waters ('Polar Code') (Res. MEPC. 264 (68)/21/Add.1, Annex 10, 15 May 2015, in force January 2017).

8 Illulisat Declaration, adopted by the coastal Arctic States on 28 May 2008. Available at http:// www.oceanlaw.org/downloads/arctic/Ilulissat_Declaration.pdf; accessed 25 August 2017.

9 Because the United Sates has not acceded to the Losc, it did not yet make its submission. Other Arctic countries, including Russia, Norway and Denmark, have filed their own claims with the Commission, the Norwegian and Danish claims opposing Russian demands. In the 
coastal Arctic States generally show a friendly attitude concerning other ongoing tensions and disputes in order to promote coordinated efforts on Arctic governance and to preserve the common interests they all share. This attitude can be seen, for example, in the only unresolved claim over landmasses (a dispute between Denmark and Canada over Has Island), in the dispute between Canada and the United States over the legal status of the NWP's waters (Canada claiming jurisdiction over the NWP and the United States claiming that these are international waters), or even in the Russia-United States and Canada tensions (Syria, Eastern Europe, mainly Ukraine ...).

\section{The $\mathrm{EU}$ in the Arctic, the Arctic in the $\mathrm{EU}$}

One of the most important, if not the most important, international actors which claim to be recognised as an Arctic stakeholder is the European Union (EU), as distinct from its member States acting either individually or collectively. The EU has not designed and developed any comprehensive and integrated Arctic policy. ${ }^{10}$ National policies overlap with EU policy. ${ }^{11}$ There are different reasons which may explain the 'dubious' Eu Arctic policy. None of the European Communities founding States was an Arctic State, and none of the coastal Arctic States is a member of the EU (except Denmark, which acceded to the European Communities in 1973 and was one of the EU founding States in 1993, though by then Greenland had already "increased" its autonomous status within the Kingdom of Denmark and had exited the European Communities). ${ }^{12}$ Finland and Sweden acceded to the EU in 1994. Mainly

Illulisat Declaration, the coastal Arctic States also agreed to negotiate disputes peacefully in the event of an overlapping claim over extended continental shelves. See C Cinelli, "The Law of the Sea and the Arctic Ocean' (2011) 2(1) Arctic Review on Law and Politics 4-24.

10 See M Campins-Eritja, 'The European Union and the North: Towards the Development of an EU Arctic Policy?' (2013) 27 Ocean Yearbook 459-585.

11 Amongst Eu member States, Denmark, Finland, France, Germany, Italy, Netherlands, Poland, Spain, Sweden and the United Kingdom have issued or are issuing Arctic or Polar policy papers. Non-EU member States that have issued an Arctic strategy or policy paper include Canada, Iceland, India, Japan, Norway, the Russian Federation and the United States of America.

12 Greenland had voted to leave the European Communities in 1982 and left in 1985. Since 1985 , the relation between Greenland and the EU is regulated by: on the one hand, specific provisions on import of fishery products originating in Greenland set out in the Protocol (No. 34) on special arrangements for Greenland, annexed to the Treaty on the European Union (TEU) (oJ C 202, 7 June 2016, 13) and the Treaty on the Functioning of the European 
because of the perceptions about the EU common fisheries policy, Norwegian people rejected twice (1972 and 1994) Norway's ratification of the accession treaties which had already been negotiated and signed. More recently, in 2009, Iceland applied to become a member of the EU, but in 2013 suspended its application..$^{13}$ However, along with Liechtenstein, Iceland and Norway are European Free Trade Association (EFTA) members and parties to the European Economic Area (EEA) agreement ${ }^{14}$ (which excludes fisheries). The EEA agreement is an important and decisive factor in shaping the parties other than EU member States' domestic legislation..$^{15}$ The EU has strategic partnerships with Canada, Russia and the United States. Those are substantial links in order to justify the EU interest in the Arctic. ${ }^{16}$ The renewed visibility of the Arctic explains the idea of a much closer cooperation in Arctic governance.

The geographical boundaries of the EU partially overlap with those of the Arctic and EU membership raises several questions, such as: the role of Arctic

Union (TFEU) (OJ C 202, 7 June 2016, 47); and, on the other hand, subject to these specific provisions, the provisions in Articles 198 to 203 of TFEU (Part Four of the TFEU, 'Association of the Overseas Countries and Territories', Arts. 198-204), as Greenland is listed in Annex II to the TFEU (Overseas Countries and Territories to which the Provisions of Part Four of the TFEU Apply) beside those territories and countries associated with the EU as non-European countries and territories which have special relations with Denmark, France, the Netherlands and the United Kingdom. In 2015, a joint declaration about closer relations between the EU and Greenland was signed by Denmark, Greenland and the EU. Anyway, citizens of Greenland are EU citizens owing to their Danish citizenship.

13 There are contradictory statements about whether Iceland has or has not withdrawn the application.

14 Agreement on the European Economic Area ( $O J$ L 1, 3 January 1994, 3).

15 Iceland and Norway are also associated countries in the EU's Horizon 2020 Framework Programme for Research and Innovation.

16 'With three Member States and two European Economic Area members being Arctic states, the EU has a strategic interest in the Arctic remaining a low-tension area, with ongoing cooperation ensured by the Arctic Council, a well-functioning legal framework, and solid political and security cooperation. The EU will contribute to this through enhanced work on climate action and environmental research, sustainable development, telecommunications, and search \& rescue, as well as concrete cooperation with Arctic states, institutions, indigenous peoples and local communities' (Shared Vision, Common Action: A Stronger Europe. A Global Strategy for the European Union's Foreign and Security Policy, presented by the High Representative for Foreign Affairs and Security Policy and Vice President of the European Commission, Federica Mogherini, to the Heads of State or Government in an urgent European Council meeting largely devoted to the outcome of the British referendum, 28 June 2016, 38-39. Available at https://europa .eu/globalstrategy/sites/globalstrategy/files/regions/files/eugs_review_web_o.pdf; accessed 25 August 2017. 
and non-Arctic EU member States in developing a EU Arctic roadmap and policy, bearing in mind the existence of EU member States' national Arctic policies; if and to what extent do Arctic EU member States 'represent' the EU in the Arctic cooperation institutions (e.g., AC):17 the influence of the EU through its law, including international agreements, particularly the EEA agreement; and the key acceptance of the EU as an Arctic stakeholder by the Arctic States and, particularly, by the coastal Arctic States. Although the EU wishes to address emerging challenges in cooperation with the Arctic partners, the EU does not seem to believe in its 'right' or 'legitimacy'18 as an Arctic stakeholder, and (at least, some of) the coastal Arctic States are suspicious about 'sharing' the Arctic with such an influent actor. ${ }^{19}$ The status of the EU in the AC might illustrate this paradox. Several non-Arctic EU member States are permanent observers, including Spain, ${ }^{20}$ but the Eu has remained excluded from acquiring

17 See C Cinelli's contribution to this special issue ('Brief consideration on EU competence within the Arctic cooperation').

18 On how the EU can achieve legitimacy in the Arctic context, see ZV Yaneva, 'Legitimate EU on the Arctic stage? Policy and interests' (2016) 20 Spanish Yearbook of International Law 233-254.

19 As Denmark, Finland and Sweden are members of the AC, some potential concerns among some of the (other) AC member States might relate to the obligation of EU member States to 'support the Union's external and security policy actively and unreservedly in a spirit of loyalty and mutual solidarity', to coordinate their action in the AC and 'uphold the Union's position' in the AC and 'keep the other member States and the High Representative informed of any matter of common interest' (Arts. 24.3 and 34 TEU). Most Arctic issues are related to areas in which EU treaties confer competence on the EU (Arts. 2 to 6 TFEU), either exclusively (e.g., the conservation of marine biological resources under the common fisheries policy) or, more frequently, a competence shared with EU member States (e.g., fisheries, excluding the conservation of marine biological resources; environment; transport; energy; and research).

20 The seven Eu member States accepted so far as observers in the AC are France, Germany, Italy, Netherlands, Poland, Spain and the United Kingdom. From the 1996 Ottawa Declaration on the Establishment of the AC, and governed by the AC Rules of Procedure, there was a difference between permanent participant status (Northern Indigenous Peoples' Organizations) and observer status in the Ac. This last position was open to non-Arctic States, inter-governmental or inter-parliamentary organizations, universal or regional, and NGOS that the Council determines can contribute to its work, primarily at the level of working groups. Since the Salekhard Ministerial Meeting in 2006, applications to obtain AC observer status were received from China, Italy and the Republic of Korea, and these states participated as ad hoc observers. In addition, the European Commission was approved as an ad hoc observer to a number of sAo meetings and has applied to become an observer to the Ac. To accommodate the growing interest of States such as China, South Korea and India, and of the EU, to participate in Council activities in a less 
this status, ${ }^{21}$ as symbolic as that acquisition might be. ${ }^{22}$ It is not the case that the EU economic and financial crisis might find a solution or mitigation in the use of Arctic resources (e.g., access to new sea routes, fishing quotas, gas and hydrocarbons, etc.). But it seems that not only are some of the governments of Arctic States reluctant with regard to a much more intense involvement of the EU in Arctic cooperation, but also the organizations representing the indigenous peoples living in the region. ${ }^{23}$

Furthermore, the EU has competences conferred by its States members in Arctic -related matters (including the development of a maritime policy, the EU

limited manner, the observer role was re-evaluated at the Tromsø Ministerial Meeting (2009), abandoning the distinction between permanent and ad hoc observers and adopting criteria that existing observers and new applicants would need to observe in order to be accepted into the AC. At the 2013 Kiruna Ministerial Meeting (2013), the Council took note of the adoption by Senior Arctic Officials of a new 'observer manual' that governs the activities of observer States and organizations; recognizing that an increase in observers could affect the balance of the AC, member States developed more robust standards, including requisite recognition of the special role of the permanent participants, but accepted Italy, along with China, Japan, South Korea, Singapore and India. See the 2013 Kiruna Declaration at https://oaarchive.arctic-council.org/bitstream/handle/11374/ 93/MMo8_Final_Kiruna_declaration_w_signature.pdf? sequence $=1 \&$ isAllowed=y. About observer status in the AC (including criteria for admittance, role of observers and AC Observer Manual for Subsidiary Bodies adopted by Senior Arctic Officials at the 2013 Kiruna Ministerial Meeting), see https://www.arctic-council.org/en/about-us/ arctic-council/observers.

The EU's application was received 'affirmatively' at the Kiruna Ministerial Meeting (2013) and the EU was accredited with the strange 'observer-in-principle' status, which was to replace the previous ad hoc regime, but a final decision was deferred until the dispute with Canada resulting from $\mathrm{EU}$ bans on seal hunting and the Arctic oil and gas production had been resolved. In April 2015, Russia also vetoed the EU's status in retaliation against its sanctions arising from the conflict in Ukraine.

The EU not only is active in programs in and channels financial support to the Arctic regions of EU member States, but it has also always participated in AC meetings and has contributed to working groups, and will continue to do so. See A Østhagen, 'In or Out? The Symbolism of the EU's Arctic Council Bid', 18 June 2013, The Arctic Institute. Available at http://www.thearcticinstitute.org/; accessed 25 August 2017.

23 The Inuit of Inuit Nunaat (from Greenland to Canada, Alaska and the coastal regions of Chukotka, Russia) do not deny the sovereignty of those States over the Arctic, but associate this sovereignty to their right to self-determination. They claim the need for global cooperation, but also stress their inclusion as active partners on Arctic sovereignty (A Circumpolar Inuit Declaration on Sovereignty in the Arctic, adopted by the Inuit Circumpolar Council, Tromsø, Norway, 28 April 2009); http://www.inuitcircumpolar.com/ uploads/3/o/5/4/30542564/declaration_on_resource_development_a3_final.pdf. 
being a party to the LOSC with no jurisdictional advantages or disadvantages compared to States parties), ${ }^{24}$ but Arctic issues affect very different EU policies and actions, both internally and externally. The great division between the Common Foreign and Security Policy (CFSP), on the one hand, and internal policies and other external action policies, on the other, is mainly reflected in the functioning and procedures of the EU institutions. But every EU policy and every action entails a fragile balance and a compromise between contradicting interests of member States and/or Eu institutions (European Parliament, Council and Commission). The Eu ban on seal products (2009), later amended to address the World Trade Organization (WTO) decision, ${ }^{25}$ did not help to make Arctic friends. But some positions of the European Parliament have been particularly unwelcome in the Arctic, notably the 2008 Resolution, which advocated pursuing the opening of international negotiations aimed at leading to the adoption of an Antarctic Treaty System-inspired international treaty for the protection of the Arctic; and the proposal to establish a moratorium on any offshore hydrocarbon exploration and extraction operations in the Arctic. Though the European Parliament abandoned the idea of an Antarctic-inspired treaty and the opinion of the Environmental Committee during Parliamentary discussions did not survive in the text of the 2013 Directive on safety of offshore oil and gas operations, ${ }^{26}$ the opponents of the participation of the $\mathrm{EU}$ in Arctic governance argued that the $\mathrm{EU}$ is far away from the political realities of the Arctic.

Anyway, there are a number of ways through which the EU may participate or have an impact on Arctic governance: either indirectly, through its influence in making or adjusting 'general' international law applicable in the Arctic and of 'Arctic-specific' international law, bearing in mind that the EU does not purport to develop a new comprehensive international legal regime for the Arctic; or directly, through 'general' or 'Arctic- specific' Eu law-which is international law but with several original features - and, subsequently, by means of EEArelevant law, mainly because the EU influences the domestic legislation of its member States and of the parties to the EEA agreement.

\footnotetext{
24 Annex IX of the LOSC ('Participation by international organizations').

25 The EU seal regime was found to be in violation of wTo law at least between 2009 and 2015. See M. Hennig's contribution to this special issue ('The Untouchable Nature of the 'EU Seal Regime'-Is the European Union Liable for the Damages Suffered by the Canadian Inuit due to the Violation of WTO Law in EC-Seal Products?').

26 Directive 2013/30/EU of the European Parliament and of the Council of 12 June 2013, amending Directive 2004/35/EC ( OJ L 178, 28.6.2013).
} 
In this regard, it is necessary to take also into account that, 'echoing' the classic debate on monism and dualism (interrelationship between international law and States' national laws), EU law has emerged as a 'new'27 law, distinct from both international law and EU member States' national laws. The interrelationship between legal systems has gained complexity, as EU law is frequently made to implement 'common' or 'ordinary' international law (EU treaties and international agreements stand as the 'epitome' of the overlapping of international law and Eu law, 'primary' and 'secondary', respectively), which once transformed or incorporated into EU law acquires a 'non-common' or 'extraordinary' nature (primacy, direct effect, etc.) within EU law in EU member States' national law, in accordance with well-settled case law of the (now) Court of Justice of the European Union (CJEU).

\section{EU Law Applicable in the Arctic ... and a 'Specific Eu Arctic Law'?}

On the basis of 'primary' EU law, 28 the EU produces 'secondary' legal acts (regulations, directives and decisions) and implements international agreements. In this way, the EU has adopted several acts in the areas of environment and climate change, social and cultural changes, energy, development of offshore oil and gas resources, mining, land use, research, maritime transport

27 Judgment of 5 February 1963, NV Algemene Transport- en Expeditie Onderneming van Gend \& Loos v. Netherlands Inland Revenue Administration-Reference for a preliminary ruling: Tariefcommissie-Pays-Bas, Case 26-62: 'the [EU] constitutes a new legal order of international law for the benefit of which the States have limited their sovereign rights, albeit within limited fields, and the subjects of which comprise not only member States but also their nationals. Independently of the legislation of member States, [EU] law therefore not only imposes obligations on individuals but is also intended to confer upon them rights which become part of their legal heritage. These rights arise not only where they are expressly granted by the treaty, but also by reason of obligations which the treaty imposes in a clearly defined way upon individuals as well as upon the member States and upon the institutions of the [EU]'.

28 The EU was established in the TEU and TFEU ('primary' EU law). The freedoms and principles set out in the Charter of Fundamental Rights of the European Union of 7 December 2000, as adapted in Strasbourg, on 12 December 2007), have the same legal value as the Treaties. The Charter was adopted in 2000 (see $O_{J} \mathrm{C}_{3} 64,18.12 .2000$ ) and adapted for mention in the Lisbon Treaty in 2007 ( $\mathrm{OJ} \mathrm{C}_{3}$ 303, 14.12.2007). The fundamental rights are also guaranteed by the European Convention for the Protection of Human Rights and Fundamental Freedoms (Rome, 4 November 1950) ETS No.005, and as they result from the constitutional traditions common to the Member States, and 'shall constitute general principles of the Union's law' (Art. 6 TEU). 
and fisheries, including research activity and regional funding destined to improve living conditions of local communities, ${ }^{29}$ which are not directly aimed at the Arctic, but sometimes specifically refer to the Arctic, ${ }^{30}$ and have an effect on the Arctic. ${ }^{31}$ Nevertheless, from the territorial scope provisions ${ }^{32}$ follow the limited direct application of this EU 'general' law: to Greenland as an overseas territory (also in accordance with the specific provisions of Art. 204 TFEU and Protocol $\mathrm{n}^{\circ} 34$ ), and to the Arctic territories of Finland and Sweden. The Arctic EU member States are the natural territory of some Arctic indigenous peoples whose rights as citizens are protected by Eu law and might be considered by the CJEU. There is still the opportunity to influence non-EU Arctic territories, policies and law via the EEA agreement, because once EU law is considered

29 See A Airoldi's report, issued by the NCM, 'The European Union and the ArcticPolicies and Actions', 2008. Available at http://dx.doi.org/10.6027/ANP2008-729; accessed 25 August 2017, and the updates 2010. Available at http://dx.doi.org/10.6027/ANP2010-763; accessed 25 August 2017 and 2014. Available at http://dx.doi.org/10.6027/ANP2014-565; accessed 25 August 2017. For comprehensive and up-to-date information to 2014 see also the main outcome of the preparatory action 'Strategic Environmental Impact Assessment of Development of the Arctic', led by the Arctic Centre of the University of Lapland and financed by DG Environment, the report 'Strategic Assessment of Development of the Arctic' (SADA), September 2014. Available at http://www.arcticinfo.eu/en/sada; accessed 25 August 2017.

30 For example, the Communication from the Commission 'An EU Strategy on adaptation to climate change' [ $\operatorname{COM}(2013), 216$ final, Brussels, 16.4.2013] specifically refers to the Arctic's particular vulnerability to the impacts of climate change. Available at http://ec.europa .eu/transparency/regdoc/rep/1/2013/EN/1-2013-216-EN-F1-1.Pdf; accessed 25 August 2017; the Joint Communication to the European Parliament, the Council, the European Economic and Social Committee and the Committee of the Regions 'International ocean governance: an agenda for the future of our oceans' [JOIN(2016) 49 final, Brussels 10.11.2016], which does not have a specific Arctic focus, although, referring to the promotion of regional fisheries management and cooperation in key ocean areas to fill regional governance gaps, it is stressed that the central Arctic Ocean is 'one of the most fragile sea regions on the planet' and that, in line with its integrated Arctic policy, 'the EU should seek to ensure sustainable development in and around the region on the basis of international cooperation'. Available at http://eur-lex.europa.eu/legal-content/EN/TXT/PDF/?ur $\mathrm{i}=$ CELEX:52016JCo049\&from=EN; accessed 25 August 2017.

31 The study 'EU Arctic Footprint and Policy Assessment. Final Report', EcoLogic, Berlin, 2010, deals with the improvement of the effectiveness of EU environmental policies with respect to the Arctic region. Available at http://arctic-footprint.eu/sites/default/files/ AFPA_Final_Report.pdf; accessed 26 August 2017.

32 EU law is applicable to member States, though EU legal acts are binding in accordance with Art. 288 TFEU and there are specific provisions on their territorial scope (Arts. $5^{2}$ TEU and 355 TFEU). 
'EEA-relevant'-i.e., within areas covered by the EEA agreement-it becomes EEA law and must be therefore incorporated into Icelandic and Norwegian domestic laws regardless of the (subsequent) will of these States. ${ }^{33}$ To be considered as EEA-relevant, an EU legal act must meet both substantive (Art. 1 EEA agreement) and geographical (Art. 126 EEA agreement) requirements. In some cases, the determination of the substantive scope of the EEA agreement is controversial (e.g., there is an obligation to cooperate closely on environmental issues, but a 'purely' environmental EU legal act might not necessarily be considered EEA-relevant by itself). ${ }^{34}$ Nevertheless, it is the geographical limitation of the EEA agreement which has turned out to be a decisive obstacle for implementing EU legislation by means of the EEA agreement in the marine Arctic. First, the Norwegian authorities expressly excluded the territory of Svalbard. ${ }^{35}$ Second, it is debatable whether the EEA agreement applies to the EEZ and continental shelf. Notably, the Norwegian authorities argue that EU legal acts which apply to the EEZ or continental shelf are not EEA-relevant

33 Non-EU member States that are parties to the EEA agreement did not confer legislative, executive or judicial jurisdiction on the EU, so EU institutions have no competence over the EFTA States. Therefore, EU law is not directly binding and is not granted primacy and direct effect in EFTA States' domestic legislation. The EU law that is EEA-relevant is integrated into the EEA agreement and, subsequently, legal acts or international agreements are, or EEA/EFTA States have to make them so, part of their internal legal order (Arts. 7 and 102 EEA agreement). The EU law adopted after 1 January 1994-when the EEA agreement entered into force-is integrated into the EEA agreement through the Annexes following a 'relevant EEA Joint Committee decision'. This means that a legal matter (the EEA relevance of EU law) is determined, on the basis of the substantive and geographical scope of EEA agreement (Arts. 1 and $126 \mathrm{EEA}$ agreement), by diplomatic means. It must be stressed that the so-called EEA two-pillar structure established in the EEA agreement, with organs composed of representatives of EU institutions and of EFTA States, does not include an EEA Court, though it is possible to ask for a ruling by the CJEU. Sometimes it may not be clear whether an EFTA State's piece of national legislation is formally implementing EEA-relevant EU law or if it is merely a piece of national legislation with no 'connection' to EU law. But when an EFTA State formally implements EEA-relevant EU law, EU practice and the decisions of the CJEU will be the reference when interpreting the content of national law.

34 The implications for the functioning of the internal market and the competition rules are the main factors, but the legal basis, the subject and the purpose, as well as the relation to an EEA-relevant EU legal act at stake are also pertinent factors to assess the EEA relevance test.

Otherwise subject to the "Svalbard Treaty", Treaty concerning the Archipelago of Spitsbergen, signed in Paris on 9 February 1920 (2 LNTS 41: 7-19). 
because they do not meet the geographical scope of the EEA agreement: ${ }^{36}$ for example the 2008 MSFD Directive, ${ }^{37}$ the 2013 Directive on safety of offshore oil and gas operations, ${ }^{38}$ or the 2016 Regulation on aviation safety. ${ }^{39}$

Several circumstances have impeded for a long time the adoption of an integrated and coherent EU Arctic policy and, even more so, EU 'Arctic-specific' legislation. The above-mentioned fragile inter-institutional balance based upon the complicated interaction between the EU institutions designed in the Treaties-notably the European Parliament, the Council and the Commission-including discrepancies amongst these institutions, and contradictory interests amongst representatives of different member States in the Council, are some of those circumstances. Similarly, an increasing sense of diplomatic prudence, together with geographical, political, legal and material constraints, have limited the EU's ability.

Despite some occasional references to the Arctic since 1989 (related to ozone layer depletion and environmental conditions, the climate changesecurity connection, the concern over future activities, and the proximity to Russia), the 'Arctic window' in the Northern Dimension policy (ND), ${ }^{40}$ and the consideration of the Arctic in the EU maritime policy, ${ }^{41}$ the EU awareness of

36 For this analysis, see E Johansen's contribution to this special issue ('The EU Influence on Norwegian Domestic Legislation for the Protection of the Arctic Marine Environment').

37 Directive 2008/56/EC of the European Parliament and of the Council of 17 June 2008 establishing a framework for community action in the field of marine environmental policy (Marine Strategy Framework Directive) ( $O J$ L 164, 25.6.2008).

38 See C Cinelli, 'Law of the Sea, the European Union Arctic Policy and Corporate Social Responsibility' (2016) 30 Ocean Yearbook 242-266.

39 Commission Regulation (EU) 2016/1199 pf 22 July 2016 amending Regulation (EU) No. 965/2012 as regards operational approval of performance-based navigation, certification and oversight of data services providers and helicopter offshore operations, and correcting that Regulation (oJ L 198, 23.7.2016).

The EU Arctic policy was preceded, once Finland and Sweden acceded to the EU, by the ND, which is a joint policy between EU, Russia, Norway and Iceland initiated in 1999 and renewed in 2006, aiming at providing a framework to: promote dialogue and concrete cooperation; strengthen stability, well-being and intensified economic cooperation; promote economic integration, competitiveness and sustainable development in Northern Europe. The ND led the EU, for example, to participate in regional and sub-regional institutions - such as the Barents Euro-Arctic Council (BEAC). Amongst others, also participating are EU member States in their national capacity and regional Councils, such as AC, BEAC, the Council of the Baltic Sea States (CBSs) and the Nordic Council of Ministers (NCM). Canada and the United States participate as observers.

41 Since the Communication from the Commission to the European Parliament, the Council, the European Economic and Social Committee and the Committee of the Regions 'An 
the Arctic relevance has been translated into specific action only since 2008 . After two previous EU communications on the Arctic (2008 and 2012), ${ }^{42}$ some European Parliament Resolutions, ${ }^{43}$ the EU Council's conclusions on Arctic issues, ${ }^{44}$ and opinions expressed by other EU organs, ${ }^{45}$ on 27 April 2016 the European Commission and the High Representative of the EU for Foreign Affairs and Security Policy presented an 'integrated and coherent' EU Arctic policy. ${ }^{46}$ This new policy document has been developed at the request of

Integrated Maritime Policy for the European Union', сом(2007), 575 final, Brussels, 10.10.2007. Available at http://www.europarl.europa.eu/RegData/docs_autres_institutions/ commission_europeenne/com/2007/0575/COM_COM(2007)0575_EN.pdf; accessed 26 August 2017.

42 Communication from the Commission to the European Parliament and the Council 'The European Union and the Arctic', сом(2008) 763 final, Brussels, 20.11.2008. Available at http://eeas.europa.eu/archives/docs/arctic_region/docs/com_08_763_en.pdf; accessed 26 August 2017, and Joint Communication from the Commission and the EU High Representative for foreign affairs and security policy 'Developing a European Union Policy towards the Arctic Region: progress since 2008 and next steps', JOIN(2012), 19 final, Brussels, 26.6.2012. Available at http://eeas.europa.eu/archives/docs/arctic region/docs/join_2012_19.pdf; accessed 26 August 2017.

43 For example, the 2008 resolution on Arctic governance. Available at http://www.europarl .europa.eu/sides/getDoc.do?type=TA\&language=EN\&reference=P6-TA-2008-474; accessed 26 August 2017, the 2011 Resolution on a sustainable EU policy for the High North. Available at http://www.europar.europaeu/sides/getDoc.do?pubRef=-//EP/TEXT+TA+P7-TA-2011$0024+0+\mathrm{DOC}+\mathrm{XML}+\mathrm{Vo} / / \mathrm{EN}$; accessed 26 August 2017; and the 2014 resolution on the EU strategy for the Arctic. Available at http://www.europar.europaeu/sides/getDoc.do?type= TA\&language $=\mathrm{EN} \&$ referebce $=\mathrm{P}_{7}-\mathrm{TA}-2014-0236$; accessed 26 August 2017 .

44 For example, its 8 December 2009 conclusions on Arctic issues. Available at http:// www.consilium.europa.eu/uedocs/cms_Data/docs/pressdata/EN/foraff/111814.pdf;accessed 26 August 2017 or 12 May 2014 conclusions on developing a EU policy towards the Arctic Region. Available at http://www.consilium.europa.eu/uedocs/cms_data/docs/pressdata/ EN/foraff/142554.pdf; accessed 25 August 2017.

45 See, for example, the European Economic and Social Committee's opinion issued in April 2013 on 'EU Arctic Policy to address globally emerging interests in the region-a view of civil society'. Available at http://eur-lex.europa.eu/legal-content/EN/TXT/PDF/?uri=CEL EX:52012IE2179\&\&rom=EN; accessed 26 August 2017.

46 Joint Communication to the European Parliament and the Council 'An integrated European Union policy for the Arctic', JOIN(2016) 21 final, Brussels, 27.4.2016. Available at http://eur-lex.europa.eu/legal-content/EN/TXT/PDF/?uri=CELEX:52016JCoo21\&from= EN, accessed 26 August 2017 . See the analysis in A. Stępień and A. Raspotnik, 'The EU's new Arctic Communication: not-so-integrated, not-so-disappointing?' (2016) The Arctic Institute, 28 and 29 April, and 3 May 2016. Available at http://www.thearcticinstitute .org; accessed 26 August 2017 and ArCticles-Arctic Center Papers, 3 May 2016. Available at 
the European Parliament and the Council ${ }^{47}$ and it is based on an indicative roadmap. ${ }^{48}$ It sets out the case for an EU policy that focuses on advancing international cooperation in responding to the impacts of climate change on the Arctic's fragile environment, and on promoting and contributing to sustainable development, particularly in the European part of the Arctic, and attaches particular importance to research, science and innovation. ${ }^{49}$ The EU's goals and ambitions are yet unclear. There are hardly any proposals for legal acts or international agreements, and there is no 'Arctic-specific' law. ${ }^{50}$

It is true that the geographical factor is here limiting the EU's ability. Not only does it hinder the implementation of EU law through the EEA agreement in the marine Arctic, it is also an obstacle for the EU regulating, for example, Arctic maritime safety and environmental protection. The Losc sets out a careful balance between the rights and obligations of flag, coastal and port States. The marine environment is purportedly protected by a universally binding minimum legal framework (codified in Part XII of LOSC), and though regional or national legislation may offer a more environmentally-friendly regulation of regional seas, there is a tradition of regulating maritime navigation

http://www.articcentre.org; accessed 26 August 2017. The policies outlined in the Joint Communication have been endorsed in Council conclusions on the Arctic of 20 June 2016. Available at http://data.consilium.europa.eu/doc/document/ST-10400-2016-INIT/ en/pdf; accessed 26 August 2017.

47 Resolution adopted by the European Parliament on 12 March 2014 and conclusions adopted by the Council (Foreign Affairs Council) on 12 May 2014.

48 Available at http://ec.europa.eu/smart-regulation/roadmaps/docs/2015_eeas_o16_arctic_ policy_en.pdf; accessed 26 August 2017 .

49 The indigenous perspective is nevertheless absent from the 2016 Communication.

5o For example, in relation to climate change and safeguarding the Arctic environment, the document affirms that the EU: should continue its engagement in multilateral environmental agreements that also have particular relevance to the Arctic, and encourage their ratification and implementation [such as the 2004 International Convention for the Control and Management of Ship's Ballast Water and Sediments, done at London, 13 February 2004 (BWM/CONF/36, 16 February 2004) and the 2013 Minamata Convention on Mercury, done at Kumamoto, 10 October 2013 (UNTS, No. I-54669)]; promote establishing marine protected areas in the Arctic; continue to support work at international level to prohibit or phase out the use of persistent organic pollutants in the environment; be ready to share regulatory (such as the Offshore Safety Directive 2013/30/EU) and technological best practice with international partners to support the safety and preservation of the environment in the region. See, in general, P Grøne, 'The European Union's Strategy towards the Arctic - A Normative Power in the Region?' (M.Sc. Thesis, Aalborg University, 2016). Available at http://www.martinbreum.dk/wp-content/uploads/2017/03/AAUDIR -Final-Thesis-.pdf; accessed 27 August 2017. 
at a universal level (IMO), minimizing the options for either a regional or more safety-oriented national regulation of navigation of vessels flagged in third States. The LOSC confirms the preference for, and prevalence of, 'generally accepted international rules or standards' relating to maritime safety. ${ }^{51}$ To sum up, national and regional legislation may improve international environmental law, but may not impose limits on navigation other than those generally accepted.

Not wishing to damage the interests of its shipping industry (competitive disadvantages, 'out-flagging', etc.), the EU regulates shipping mainly based on port State jurisdiction, ${ }^{52}$ less commonly based on coastal State jurisdiction, ${ }^{53}$

$5^{1} \quad$ For example, Art. 21 LOsC permits a coastal State to adopt laws and regulations relating to innocent passage through the territorial sea, but such laws and regulations shall not apply to the design, construction, manning or equipment of foreign vessels 'unless they are giving effect to generally accepted international rules or standards'. See also Arts. 6o, $197,208,209,211,213-220,222,226,228,230,297$ LOSC. It is not controversial that every flag State may complement or exceed the international rules and standards by imposing requirements on vessels flying its flag. In contrast to the detailed regime for coastal States' jurisdiction over foreign vessels, the LOsC does not provide much guidance on the extent to which port States may impose requirements other than those generally accepted on those vessels voluntarily visiting their ports. It is generally accepted that foreign vessels have no general right of access to ports and that port States may condition their entry [Arts. 25.2 and 211.3 LOSC, and ICJ judgment of 27 June 1986, Military and Paramilitary Activities in and against Nicaragua (Nicaragua v. United States of America), para. 213, p. 101], but there is no precise regulation of the 'particular requirements' which they may impose, including the eventual port State's jurisdiction on casualties and incidents beyond its own national maritime zones.

52 Directive 2009/16/EC of the European Parliament and of the Council on port State control (oJ L 131, 23.4.2009) is especially relevant.

53 The law of the sea imposes strict limitations on coastal States' jurisdiction over navigation of foreign vessels through their coastal waters, with regard to legislative measures other than the generally accepted international rules and standards or enforcement measures which anyway involve complex, costly and potentially dangerous actions at sea. The three EU Directives that apply to vessels that are merely passing through the waters of the member States are: Directive 2002/59/EC of the European Parliament and of the Council of 27 June 2002 establishing a Community vessel traffic monitoring and information system (VTMIs Directive) (oJ L 208, 5.8.2002); Directive 2005/35/EC on ship-source pollution and on the introduction of penalties, including criminal penalties, for pollution offences (oJ L 2555, 2005); and Directive 2016/802/EC relating to a reduction in the sulphur content of certain liquid fuels ( $O J \mathrm{~L} 132,2016)$. These three Directives to some extent even extend beyond member States' coastal waters to the high seas (e.g., Directive 2005/35 applies to offences that have taken place even on the high seas). 
and hardly ever exclusively based on flag State jurisdiction, ${ }^{54}$ even though the same EU legal act may simultaneously involve port, coastal and/or flag State jurisdictions.

Although there are a number of ways other than regulation by which the EU could exert influence in the Arctic, there are options that have not yet been fully explored even within the legal domain. ${ }^{55}$ The Eu legal acts exclusively focused on vessels flagged in an EU member State do not include a geographic limitation, but they might entail a comparative disadvantage for its shipping industry. ${ }^{56}$ Other EU legal acts that apply to vessels flagged in third States, and also to vessels flagged in EU member States, may not include a geographical limitation and they are therefore applicable to the latter vessels wherever they may operate, including the Arctic, though these acts implement widely accepted IMO and International Labor Organization (ILO) rules. ${ }^{57}$ The

54 These EU legal acts that focus on vessels operating in the coastal waters and/or ports of member States also apply to vessels flagged in a member State: e.g., Directive 2000/59/EC of the European Parliament and of the Council of 27 November 2000 on port reception facilities for ship-generated waste and cargo residues ( $O J \mathrm{~L}$ 332, 28.12.2000); the VTMIS Directive ( $\mathrm{n}_{53}$ ).

55 See HM Ringbom, 'The European Union and Arctic Shipping' in N Liu, EA Kirk and T Henriksen (eds), The European Union and the Arctic (Brill-Nijhoff, Leiden, 2017) 237-273.

56 For this reason, these legal acts are few and usually target the administration rather than vessels, for example: training for seafarers [Directive 2001/25/EC of the European Parliament and of the Council of 4 April 2001 (oJ L 136, 18.5.2001)], repealed by Directive 2008/106/EC of 18 November 2008 (oJ L323, 3.12.2008)]; ship inspection, survey organizations and maritime administration requirements [Directive 2009/15/EC of the European Parliament and of the Council of 23 April 2009 ( $O J \mathrm{~L}$ 131, 28.5.2009)]; compliance with flag State requirements [Directive 2009/21/EC of the European Parliament and of the Council of 23 April 2009 (OJ L 131, 28.5.2009)]. The exception was, perhaps, EU's double-hull requirements on oil tankers: Regulation (EC) No 457/2007 of the European Parliament and of the Council of 25 April 2007 amending Regulation (EC) No 417/2002 on the accelerated phasing-in of double-hull or equivalent design requirements for single-hull oil tankers, which provided that '[n]o oil tanker carrying heavy grades of oil shall be allowed to fly the flag of a Member State unless such tanker is a double-hull tanker' (oJ L 113, 30.4.2007), See HM Ringbom, EU Maritime Safety Policy and International Law (Martinus Nijhoff Publishers, Leiden, 2008) 172-173.

57 For example, Regulation (EC) No 782/2003 of the European Parliament and of the Council of 14 April 2003 on the prohibition of organotin compounds on ships (oJ L 115, 9.5.2003); Regulation (EC) No 336/2006 of the European Parliament and of the Council of 15 February 2006 on the implementation of the International Safety Management Code within the Community (oJ L 64, 4.3.2006); and Directive 2009/20/EC of the European Parliament and of the Council of 23 April 2009 on the insurance of shipowners for maritime claims (oJ L 131, 28.5.2009). 
applicability of EU legal acts focused on coastal State jurisdiction in an Arctic context is limited to the coastal waters of non-EU member Arctic States that are parties to the EEA agreement (Iceland and Norway), as long as those acts meet the geographical scope of the EEA agreement, or where the obligations assumed based on the EEA agreement have been extended beyond this geographical scope. ${ }^{58}$ Thus, the EU legal acts based on port State jurisdiction imposing requirements also on foreign vessels visiting its member States' ports - which include as a last resort the prohibition to enter any EU member State's port-are those which offer the better options to influence Arctic maritime safety and environmental protection: sometimes these legal acts merely implement international rules and standards, including the International Code for Ships Operating in Polar Waters ('Polar Code'); 59 whereas at other times, EU legal acts apply international rules which have not come into force yet; ${ }^{60}$ and finally, it could be the case that those legal acts implement recommendations ${ }^{61}$ or include EU requirements that go beyond international rules and standards. ${ }^{62}$ These EU requirements—-which may be effective because an

$5^{8}$ It appears that Iceland and Norway have acknowledged the geographical applicability of the 2002 VTMIS Directive, the 2005 Directive on ship-source pollution and penalties for pollution offences, and the 2016 Directive on sulphur in fuels. These Directives are substantively not very demanding and none of them significantly affects rights and obligations in an Arctic context. The 2005 Directive does not extend to third States' coastal waters and the transpolar routes in the Arctic run through the coastal waters of Canada and Russia. Ringbom ( $\mathrm{n} 55)$.

59 Resolution MEPC.264(68) (http://www.imo.org/en/KnowledgeCentre/IndexofIMOReso lutions/Marine-Environment-Protection-Committee-(MEPC)/Documents/MEPC $.264(68) \cdot$ pdf).

60 Regulation (EC) No. $782 / 2003$ on the prohibition of organotin compounds on ships (oJ L 115, 2003) implements the International Convention on the Control of Harmful AntiFouling Systems on Ships (AFS Convention), adopted 5 October 2001, entered into force 17 September 2008 (AFS/CONF/26, 18 October 2001); and Regulation 336/2006 on the implementation of the International Safety Management Code within the Community (oJ L 64, 4.3.2006).

61 Council Regulation 2978/94 on the implementation of Imo Resolution A.747(18) on the application of tonnage measurement of ballast spaces in segregated ballast oil tankers (oJ L 319, 12.12.1994) and Directive 2001/96/EC of the European Parliament and of the Council of 4 December 2001 establishing harmonized requirements and procedures for the safe loading and unloading of bulk carriers $($ oJ L 13, 16.1.2002).

62 Either 'static' requirements [the rule banning single-hull oil tankers from European ports, since the entry into force of Regulation (EC) No. 1726/2003 of the European Parliament and of the Council of 22 July 2003 amending regulation (EC) No. 417/2002 on the accelerated phasing-in of double-hull or equivalent design requirements for single-hull oil 
important share of Arctic traffic enters EU/EEA ports, and may increase in the future-may go further, ${ }^{63}$ though they have occasionally been proven controversial, as was notably the case of the regulation for monitoring, reporting and verification of $\mathrm{CO}_{2}$ emissions. ${ }^{64} \mathrm{~A}$ weaker link to international rules, or to the territorial interests of the EU itself, will normally also weaken the legal case for the EU's regulatory jurisdiction. ${ }^{65}$

\section{The EU, International Law and the Arctic}

International legal frameworks where the EU plays a role, such as the LOSC, the Imo conventions (not only the Polar Code) and the 1992 United Nations Framework Convention on Climate Change (UNFCCC), ${ }^{66}$ also cover the Arctic. Moreover, the EU is engaged in issues of direct relevance to the Arctic

tankers (oJ L 249, 1.10.2003), to the enttry into effect (5 April 2005) of the 2003 amendments to Regulation 20 of Annex I to MARPOL 73/78]; the VTMIs Directive] or 'non-static' or operational requirements [Directive 2005/35 on ship-source pollution and penalties for pollution offences; Regulation (EU) No. 2015/757 of the European Parliament and of the Council of 29 April 2015 on the monitoring, reporting and verification of carbon dioxide emissions from maritime transport, and amending Directive 2009/16/EC (oJ L 123, 19.5.2015); 2016 Directive on sulphur in fuels].

63 Concerning the implementation and enforcement of international rules in EU ports through Directive 2005/35 and using port State jurisdiction rights according to Art. 218 LOSC.

64 The European Parliament, in its first reading report on the revision of the EU emissions trading system (ETS), demanded that the IMO have a system comparable to the EU ETS available for global shipping by 2021. If this does not occur, then shipping will, according to the European Parliament, be included in the EU ETS as from 2023 [amendments adopted by the European Parliament on 15 February 2017 on the proposal for a Directive of the European Parliament and of the Council amending Directive 2003/87/EC to enhance cost-effective emission reductions and low-carbon investments-EP Doc. P8_TA (2017)0035, proposed new chapter IIa (arts. 3ga-3ge). Available at http:// www.europarl.europa.eu/sides/getDoc.do?type=TA\&reference $=$ P8-TA-2017-0035\& language=EN; accessed 27 August 2017].

65 Some relevant considerations are: the substantive nature of the rule in question ('static' features of the ship v. questions of operation or behavior); the choice of measures taken to enforce the requirement in question; other legal obligations (international trade law, non-discrimination or abuse of right obligations), which may limit the exercise of port State's jurisdiction against foreign ships; the objective of the measure (common values or resources); the existence or not of international rules or standards, etc. Ringbom (n 55).

66 United Nations Framework Convention on Climate Change, done at New York, 9 May 1992 (UNTS, vol. 1771, I-30822, p. 107). 
at the international level via the UN and its specialized agencies (the IMO and the International Civil Aviation Organization (ICAO)) and subsidiary bodies (the United Nations Environmental Programme). Though at the beginning there may have been some reluctance even amongst member States themselves (they did not expressly confer legal personality on the EU until the entry into force of the Lisbon Treaty), the EU is generally recognized as an international actor. Otherwise, without a recognized international legal personality and a CSFP, the EU could not respond efficiently to global challenges and endorse the values which it is committed to uphold and promote in its relations with the wider world, and defend its interests, contributing to peace, human rights and sustainable development in Europe and beyond.

In this sense, the EU has interacted with third States, international organizations and other international actors, and has promoted the adoption of international law rules and standards, and their modification when these were not wholly satisfactory for the values and interests of the EU, its States members and its citizens. The political, legal and material constraints on the EU's legal capability and political reality in order to perform as an actor in the Arctic do only not apply to this geographical area, yet are also present worldwide. These limitations are dependent upon the area where the action is pursued. However, the 2016 Joint Communication affirms that the $\mathrm{EU}$ should take an active negotiating position in relevant UN fora to encourage all countries and regions to assume their responsibilities, notably regarding climate change and environmental protection, but also in relation to emerging challenges such as safety at sea and the sustainable management of land- and sea-based resources.

\section{The EU and 'General' International Law Applicable in the Arctic}

The Arctic is formed by its inhabitants and a diversity of species and resources, spread over land territories, marine zones, ice and air space subject to sovereignty (land areas, internal waters and territorial sea, and the air space over them as well as the bed and subsoil of its territorial waters) or national jurisdiction (contiguous zones, EEZs and continental shelves) and beyond national jurisdiction (high seas, the international seabed Area and the air space over waters beyond the outer limit of the territorial sea). The sovereignty and jurisdiction of States and their other competences are exercised in the Arctic, as everywhere else, subject to 'general' rules of international law.

The Eu has taken a leading role in several fields within the scope of 'general' international law applicable in the Arctic. As a 'civilian' (or 'soft') power, the EU plays an important role in international commercial, economic and financial law, human rights law, environmental law, law of the sea (e.g., sustainable 
fisheries, protection of marine biodiversity), ${ }^{67}$ etc. Notably, the EU has compromised internationally in the fight to mitigate climate change, and so efforts towards mitigation and adaptation to climate change are particularly supported by the EU (UNFCCC, Kyoto Protocol, ${ }^{68} 2015$ Paris Agreement). ${ }^{69}$ These efforts necessarily have an impact on the Arctic, a region highly sensitive to climate change..$^{70}$ Moreover, all EU member States have traditionally been funders of scientific programmes and the EU is currently investing in Arctic scientific research. The EU and its member States are also promoters of the rights of indigenous peoples.

As mentioned above, the EU has defended its interests and values in international fora accompanying efforts on the negotiation table with the adoption of EU legislation complementary to, or even in contradiction with, international rules, should those international rules be considered as producing inadequate solutions. Nevertheless, the EU is subject to 'general' international law and most of the EU rules are in line with internationally agreed rules and standards. Dealing with Arctic issues, the EU has an increasing tendency to avoid controversies with (mainly coastal) Arctic States, ${ }^{71}$ looking for international cooperation with Arctic States and other Arctic stakeholders and leaving the substantive regulation to universal institutions.

\section{International Arctic Law and the $\mathrm{E} U$}

Leaving aside the initial idea of the European Parliament to adopt an Antarctic Treaty System-inspired international treaty for the protection of the Arctic, the Commission has positioned itself with Arctic States in favour of maintaining the existing multilateral mechanism and refraining from the adoption of new legal instruments. In a 2016 joint communication, the EU considered that the

67 See the contribution to this special issue by R Churchill ('The EU as an actor in the Law of the Sea, with particular reference to the Arctic').

68 Kyoto Protocol to the United Nations Framework Convention on Climate Change, 11 December 1997 (UNTS, vol. 2303, A-30822, p.162).

69 Paris Agreement. Paris, 12 December 2015 (UNTS, I-54113).

70 See, for example, N Dobson's and S Trevisanut's contribution to this special issue ('Climate change and energy in the Arctic Ocean: The role of the EU').

71 The exception has been, years ago, the European Parliament: not only did the 2008 Resolution advocate the adoption of an Antarctic Treaty System-inspired specific Arctic international treaty, but, also with the Arctic in mind, the 2011 Resolution called for the EU to adopt supplementary port-State measures 'with a view to imposing a strict regime limiting soot emissions and the use and carriage of heavy fuel oil' if the international negotiations at the Imo did not produce the desired results. The European Parliament's 2014 Resolution did not retain this call. 
leading role in addressing the emerging issues in the region remains in hands of the eight Arctic States, even though these issues can be more effectively addressed through partnership.

In 2011, 2013 and 2017, the Arctic States have adopted, under the exclusive AC auspices, three agreements related to search and rescue activities, ${ }^{72}$ marine oil pollution response in the Arctic ${ }^{73}$ and Arctic scientific cooperation..$^{74}$ Only the Arctic States may be 'parties' to the 2013 and 2017 agreements, although there are similar provisions related to cooperation with non-parties. ${ }^{75}$ Despite the existence of subjects such as navigation, piracy, terrorism, smuggling, etc., directly affecting the EU member States' territories, there has thus been a limited participation of the EU and all non-Arctic European States have been excluded from the negotiation and adoption processes. The AC may become a proper international organization; it may broaden its competences to encompass even security and defence issues or the Arctic States may in some other way encompass cooperation in that issues. The role of the EU in AC is still pending, awaiting the Arctic States' definitive decision.

72 In the 2009 Tromsø Declaration, on the occasion of the Sixth Ministerial Meeting of the Arctic Council, the eight Arctic States decided to establish a task force to develop the Agreement on Cooperation on Aeronautical and Maritime Search and Rescue in the Arctic, which was adopted in Nuuk on 12 May 2011. See the Declaration at https://oaarchive .arctic-council.org/bitstream/handle/11374/91/o6_tromso_declaration_2009_signed\%20 $\% 281 \% 29 . p d f$ ?sequence=1\&isAllowed=y, and the Agreement at https://oaarchive.arcticcouncil.org/bitstream/handle/11374/531/EDOCS-1910-v1-ACMMDKo7_Nuuk_2011_Arctic_ SAR_Agreement_unsigned_EN.PDF?sequence $=8$ \&isAllowed $=\mathrm{y}$.

73 In the 2011 Nuuk Declaration on the occasion of the Seventh Ministerial Meeting of the Arctic Council, ministers representing the eight Arctic States decided to establish a task force to develop the Agreement on Cooperation on Marine Oil Pollution Preparedness and Response in the Arctic, done at Kiruna on 15 May 2013. See the Nuuk Declaration at https://oaarchive.arctic-council.org/bitstream/handle/11374/92/o7_nuuk_declaration 2011_signed.pdf?sequence=1\&isAllowed=y; and the Agreement at https://oaarchive .arctic-council.org/bitstream/handle/11374/529/EDOCS-2068-v1-ACMMSEo 8 KIRUNA_2013_agreement_on_oil_pollution_preparedness_and_response_signed Appendices_Original_130510.PDF?sequence=6\&isAllowed $=\mathrm{y}$.

74 At the 8th Ministerial meeting in Kiruna, Sweden, in 2013, Ministers of the Arctic States mandated the creation of a Task Force 'to work towards an arrangement on improved scientific research cooperation among the eight Arctic States'. The culmination of this work came at the 1oth Ministerial meeting in Fairbanks, Alaska on 11 May 2017, with the signature of the Agreement on Enhancing International Arctic Scientific Cooperation (see the Agreement at https://oaarchive.arctic-council.org/handle/11374/1916).

75 Art. 18 of the 2011 Agreement and Arts. 17 of the 2013 and 2017 Agreements. 
Moreover, international (universal) maritime rules have not traditionally singled out the Arctic as an area where specific rules apply (Art. 234 LOSC is an exception), ${ }^{76}$ but this has partially changed since IMO adopted the 'Polar Code' and related amendments to make it mandatory under three key IMo Conventions: the International Convention for the Safety of Life at Sea (solas), the International Convention for the Prevention of Pollution from Ships (MARPOL), and the International Convention on Standards of Training, Certification and Watchkeeping for Seafarers (sTCW). ${ }^{77}$

The EU has recently insisted in the necessity to deepen international cooperation in Arctic issues. For example, the 'agenda for the future of our oceans' refers to the promotion of regional fisheries management and cooperation in key ocean areas to fill regional governance gaps, and specifically to the central Arctic ocean. Notably, in line with its integrated Arctic policy, it is highlighted that the EU should seek to ensure sustainable development in and around the region on the basis of international cooperation. In particular, it will support the creation of an Arctic RFMO/Arrangement and promote biodiversity protection through the establishment of MPAs.' ${ }^{78}$

$7^{6}$ Canada and Russia have made use of this jurisdiction, and Denmark has indicated its intention to do so regarding Greenland's waters within the limits of the EEz. The option of using this article is not open to Norway (except for the Svalbard archipelago's coastal waters, subject to the 1920 Paris Treaty) and Iceland because their EEZ are not ice-covered for most of the year.

77 The International Convention for the Safety of Life at Sea (solas), concluded at London, 1 November 1974 (UNTS, vol. 1184, I-18961, p. 2), as amended; the International Convention for the Prevention of Pollution from Ships (MARPOL), concluded at London on 2 November 1973 and 17 February 1978 (UNTS, vol. 1340, 1-22484, pp. 62 and 184), as amended; and the International Convention on Standards of Training, Certification and Watchkeeping for Seafarers (stCW), done at London, 7 July 1978 (UNTS, vol. 1361, I-23001, p. 190). The Polar Code and solas amendments were adopted during the 94th session of IMO's Maritime Safety Committee (MSC) in November 2014; the environmental provisions and MARPOL amendments were adopted during the 68th session of the Marine Environment Protection Committee (MEPC) in May 2015. Chapter 12 of the Polar Code on manning and training says that companies must ensure that masters, chief mates and officers in charge of a navigational watch on board vessels operating in polar waters have completed appropriate training, taking into account the provisions of the sTCW and its related sтCW Code. Mandatory minimum requirements for the training and qualifications of masters and deck officers on vessels operating in polar waters were also adopted by IMO's MSC in November 2016. They shall become mandatory under the STCW Convention and the sTcW Code from 1 July 2018. The Polar Code entered into force on 1 January 2017.

$78 \quad \operatorname{JOIN}(2016) 49$ final, Brussels 10.11.2016. 


\section{International Law and the Arctic through E U Law}

Under EU law, and national and international law, EU member States are required to comply with EU law (treaties, directives, regulations, decisions, international agreements). The TEU and TFEU, and bilateral and multilateral international agreements concluded by the EU with third States and international organizations (e.g., LOSC, UNFCCC) are truly international law. Most of the EU 'secondary' legal acts, which are also international law (and may be 'EEA-relevant'), are based on-or directly copy—rules that also feature at the international level (e.g., many of the EU legal acts which apply to vessels voluntarily entering a port of a EU member State, independently of their flag, and implement international IMO/ILO rules and standards).

When the Eu legal acts extend beyond international rules-i.e., adding substantive requirements to universal international law, sometimes to promote a diplomatic negotiation, or advancing the entry into force-, it may either be controversial (e.g., the double-hull regulation and the regulation for monitoring, reporting and verification of $\mathrm{CO}^{2}$ emissions) or it may even be found to be in violation of international law (e.g., the EU ban on seal products was found to be in violation of WTO law).

But even when EU law merely copies international rules, the EU still adds value to the 'force' or efficacy ${ }^{79}$ of these rules. This is the case when: Eu law harmonizes its implementation across the EU and its member States, irrespective of formal adherence to the international rule in question; it brings international obligations into the realm of Eu law (direct effect, primacy, etc.), strengthening significantly the legal tools available against EU member States and persons under their jurisdiction that fail to implement them;80 and it may extend the scope of application to non-EU member States that are parties to the EEA agreement. This reinforcement of international law largely compensates for the lack of enforcement of several international agreements in some relevant Arctic States (LOSC, Kyoto Protocol to UNFCCC and 2015 Paris Agreement).

\footnotetext{
79 For example, the adoption at the regional level (EU/EEA) of measures based on port State jurisdiction avoids the risk of 'ports of convenience', whereby ship operators could evade the requirements by simply choosing another port of destination.

$80 \quad$ In this sense, see Ringbom ( $\mathrm{n} 55$ ).
} 
Copyright of International Journal of Marine \& Coastal Law is the property of Martinus Nijhoff and its content may not be copied or emailed to multiple sites or posted to a listserv without the copyright holder's express written permission. However, users may print, download, or email articles for individual use. 